\title{
A 14,000-YR FIRE HISTORY FROM THE MIXED CONIFER FOREST OF SOUTHERN Yellowstone National PARK
}

\author{
CATHY WHITLOCK $\downarrow$ ROSEMARY SHERRIFF \\ DEPARTMENT OF GEOGRAPHY $\downarrow$ UNIVERSITY OF OREGON \\ EUGENE
}

\section{$\downarrow \quad$ INTRODUCTION}

The Yellowstone region has been divided into geovegetation regions based on characteristics of the vegetation, climate, and geology (Despain, 1990). The Northern Range or Yellowstone-Lamar valleys features open Douglas-fir parkland, summerwet conditions, and substrates composed of glacial debris and sedimentary and granitic material. The Central Plateau is an area of lodgepole forest, relatively dry summers, and infertile rhyolite soils. The Absaroka region consists of mixed conifer forest, relatively dry summers, and andesitic and sedimentary rock types. The environmental history of the geovegetation regions, as revealed from a network of pollen and charcoal records, has been equally distinctive (Whitlock, 1993; Whitlock and Bartlein, 1993; Whitlock et al., 1994, 1995). The Northern Range experienced wetter-than-present summers in the early Holocene between 10 and $7 \mathrm{ka}$ ( $\mathrm{ka}=1000{ }^{14} \mathrm{C}$ years before present) as a result of intensified monsoonal circulation. The development of Douglas-fir parkland there has occurred with drying in the late Holocene. The paleoecologic record shows few fires in the early Holocene and increased burning in the last 7000 years as the climate became drier (Millspaugh, in prep.). In the Central Plateau, areas of rhyolite supported lodgepole-pine forest for the last 10,000 years with little change. Charcoal data from this region indicate that fires were most frequent in the early
Holocene between 10 and $7 \mathrm{ka}$, when southern and central Yellowstone National Park (YNP) and Grand Teton National Park (GTNP) were warmer and drier than at present. Fire frequency has decreased in the last few millennia with the onset of present-day cool conditions (Millspaugh, in prep.; Whitlock and Millspaugh, in press). Despite these changes in Holocene climate and fire regime the vegetation of the Central Plateau remained a lodgepole pine forest, presumably because of the infertile soils.

The long-term fire history of the Absaroka region is not well known, although some information is available on the vegetation and climate history. The andesitic soils support a dense forest of spruce, fir, and pine today that features some of the oldest trees in the YNP. Dendrochronologic evidence suggest long fire return intervals (up to $400 \mathrm{yrs}$ ) and severe stand replacement events characterize the present-day fire regime (Barrett, 1994). Like the Central Plateau, the Absaroka region lies in the summer-dry area (Despain, 1987), and paleoecologic data suggest that it also experienced greatest summer drought in the early Holocene, ca. 10-7 ka. When summers were warmest, the pollen data show an increase in fireadapted species, such as Douglas fir and lodgepole pine. As the climate became cooler and more humid in the late Holocene, mesophytic species like Engelmann spruce, subalpine fir, and whitebark pine increased in abundance (Whitlock, 1993; Baker, 
1976). In this report, we describe the paleoenvironmental record of Trail Lake (Lat. $44^{\circ} 18^{\prime}$, Long. $110^{\circ} 10^{\prime}$, elev. $2362 \mathrm{~m}$ ) in the Absaroka region of southern YNP to examine the long-term fire history associated with the vegetational and inferred climatic changes. We hypothesize that both the vegetation and fire history at Trail Lake should show a strong response to changes in regional climate, in contrast with the Central Plateau where the long-term climate-fire linkage is well-expressed but the climate-vegetation interactions are weakly developed (Whitlock and Millspaugh, in press; Millspaugh, in prep.).

Trail Lake was chosen for this study for several reasons: First, it is located in spruce-firwhitebark pine forest on glacial deposits of andesitic origin. Second, the vegetation and climate history of this region is reasonably well-known from pollen data at Buckbean Fen (Baker, 1976), Mariposa Lake (Whitlock, 1993), and Cub Creek Pond (Waddington and Wright, 1974). Third, the site was burned in 1988, and charcoal samples collected in October 1988 allow us to calibrate the prehistoric record. The calibration of charcoal abundance with known fire events has been an essential step in our reconstruction of past fires (Millspaugh and Whitlock, 1995; Whitlock and Millspaugh, 1996; Whitlock et al., 1997). Fourth, Trail Lake lies in an area that has been regularly burned by fires originating from the south and southwest. The site will provide new information on the frequency of such fires in the past.

\section{$\downarrow \quad$ METHODS}

In August 1996, a 10.03-m-long sediment core was retrieved from Trail Lake using a modified Livinstone piston corer from an anchored platform. The core was taken in the center of the lake where the water depth was $3.22 \mathrm{~m}$. The core was extruded in the field wrapped in cellophane and foil and transported back to the laboratory where it was refrigerated. A 20 -cm-long surface core was obtained at the same location to obtain the mudwater interface. This core was extruded vertically and sampled at $1-\mathrm{cm}$ intervals in the field.

Pollen samples were processed with standard methods (Faegri et al., 1989). Known quantities of Lycopodium spores were added to each sample in order to achieve a ratio of ca. 3:1 fossil pollen to Lycopodium spike for calculation of pollen concentration. Pollen residues were examined at magnifications of 400 and $1000 \mathrm{X}$, and a minimum of 300 terrestrial pollen grains and fern spores were counted for 36 samples distributed throughout the core. The pollen stratigraphy with this sampling interval is generalized, and the density of samples will be increased when radiocarbon dates are available (see below).

Pollen identifications were based on comparison with the reference collection of modern pollen at the University of Oregon and published atlases (e.g., McAndrews et al., 1973; Moore and Webb, 1978). Pollen grains that could not be identified with the available reference materials were listed as Unknown. Grains that were degraded beyond recognition or obscured were listed as Indeterminate. Haploxylon-type Pinus grains were assigned to $P$. albicaulis (whitebark pine) and $P$. flexilis (limber pine), and Diploxylon-type Pinus was attributed to $P$. contorta (lodgepole pine) based on modern phytogeography. Pinus pollen that lacked a distal membrane and were listed as Pinus Undifferentiated. Terrestrial pollen data were expressed as percentages of total terrestrial (nonaquatic) pollen and spores counted at each level. Aquatic taxa were presented as a percentage of all pollen and spores.

The fire history reconstruction was based on an analysis of macroscopic charcoal particles ( $>125 \mu \mathrm{m}$ diameter) in contiguous samples (See Millspaugh and Whitlock, 1995; Long et al., in review for rationale). We chose a sampling interval of $1 \mathrm{~cm}$, which prior experience has shown represents a deposition of time of ca. 10 years in small Yellowstone lakes. With this sampling interval, we will be able to document fire occurrences at decadal-to-millennial time resolution. Fire events in this study means one or more fires occurring within or near the watershed in a particular decade.

Subsamples of $5 \mathrm{~cm}^{3}$ for charcoal analysis were taken from each $1-\mathrm{cm}$ interval and disaggregated in a solution of dilute sodium hexametaphosphate for $24 \mathrm{hr}$. Macroscopic charcoal particles were analyzed because they are not transported long distances from a fire (Patterson et al. 1987; Clark 1990; Whitlock and Millspaugh 1996). Whitlock and Millspaugh (1996), for example, found that macroscopic charcoal particles ( $>125 \mu \mathrm{m}$ in diameter) were abundant in lakes that lay within a $10 \mathrm{~km}$ radius of the 1988 Yellowstone 
fires but were scarce at greater distances. Sediment samples were gently washed through nested sedimentologic screens (mesh sizes of 125 and 250 $\mu \mathrm{m}$ diameter), and particles were tallied under a stereomicroscope. Charcoal counts were presented as charcoal concentration.

When radiocarbon dates become available charcoal concentration data will be converted to charcoal accumulation rates (pieces $/ \mathrm{cm}^{2} / \mathrm{yr}$ ), and the record will be decomposed into charcoal background and charcoal peaks. Background levels provide information on changes in woody fuel biomass and charcoal delivery and deposition through time. The peaks represent fire events, and their frequency allows an estimation of the number fire events/millennia (Long et al., in review).

Sediment magnetism has been used to infer changes in the clastic input to a lake (Thompson and Oldfield 1986; Rummery et al., 1979). Fires remove the organic layer of soils, which can destabilize slopes (Swanson 1981), and heat soils, which can increase the formation of paramagnetic minerals (Thompson and Oldfield 1986); both processes may increase the magnetic susceptibility of sediments deposited in a lake. Variations in runoff, streamflow, and mass movement unrelated to fire can also produce a change in the magnetic susceptibility of sediments. Magnetic susceptibility readings were taken on an $8-\mathrm{cm}^{3}$ subsample from each $1-\mathrm{cm}$ interval before the charcoal analysis was performed. Electromagnetic units $\left(\mathrm{emu} / \mathrm{cm}^{3}\right)$ will be divided by sample deposition time $(\mathrm{yr} / \mathrm{cm})$ to calculate magnetic susceptibility influx $\left(\mathrm{emu} / \mathrm{cm}^{2} / \mathrm{yr}\right)$. The resulting data will be decomposed in the same way as the charcoal accumulation rates.

The \% organic and carbonate content of the core was determined using weight-loss on ignition methods described by Dean (1974). Samples were taken at 10- and 20-cm intervals in the core.

\section{PRELIMINARY RESULTS AND DISCUSSION}

\section{LITHOLOGIC HISTORY}

The core stratigraphy is shown in Figure 1. The upper $8.61 \mathrm{~m}$ (3.22-11.83 m depth) consisted of fine detritus gyttja (11-35\% organics and <5\%

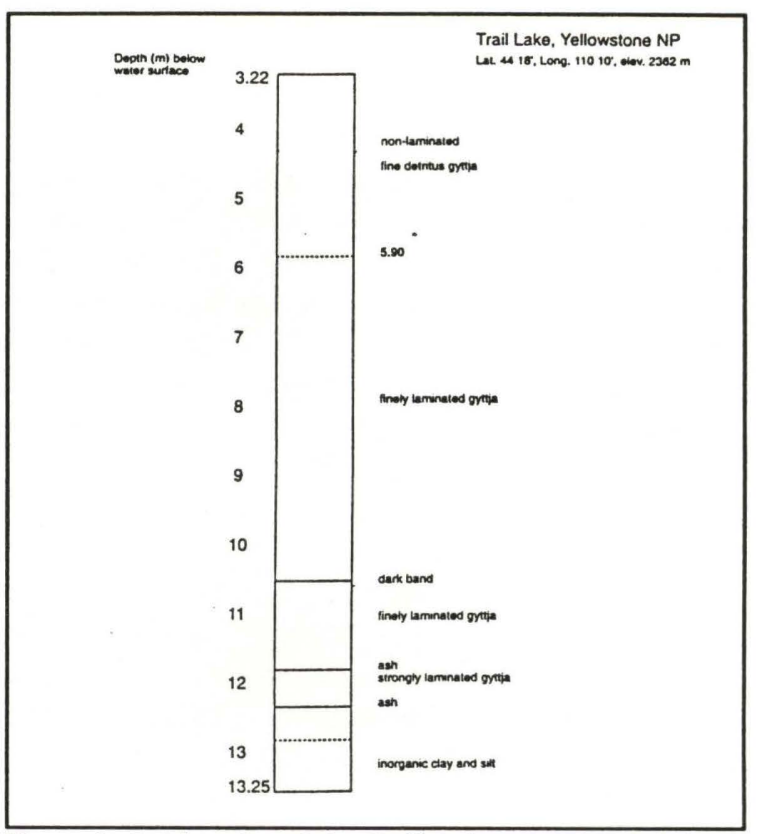

Figure 1. Stratigraphy of the Trail Lake core. Note deths are measured from water surface.

carbonates). The most organic sediments (35\% organic content) were found in the upper meter of the core (Fig. 2). Magnetic susceptibility readings are generally low in this interval, implying little

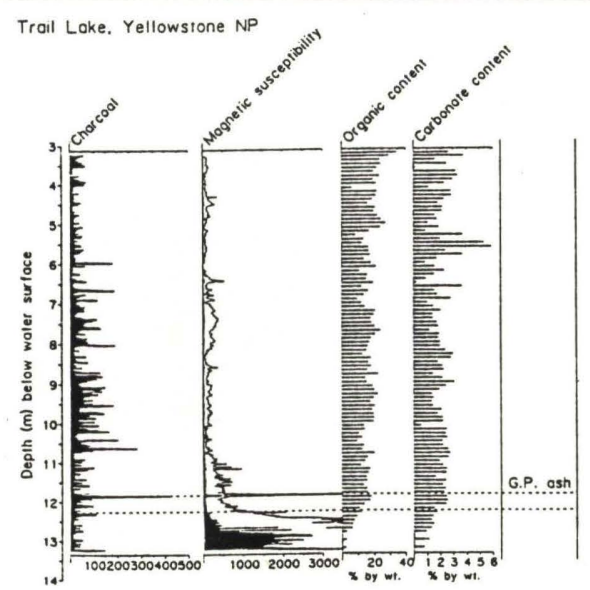

Figure 2. Charcoal concentration (number of particles $/ \mathrm{cm}^{3}$ ), and organic and carbonate content based on weight-loss on ignition (Dean, 1974).

input of clastic material. From 5.90 to $11.83 \mathrm{~m}$ depth the sediments contain decimeter-thick intervals with finely laminated layers of pure diatoms. At 11.83-11.84 and 12.24-12.25 $\mathrm{m}$ are two volcanic ash layers. These tephra occur in a part of the core where the organic content is declining from ca. 20\% to $10 \%$, which suggests that they are from lateglacial eruptions of Glacier Peak. These eruptions 
have been dated at ca. $11.8 \mathrm{kyr}$ in other lakes in the YNP/GTNP region (Whitlock, 1993). Between the ash layers are a series of distinctive 1-mm-thick light and dark layers, which appear to be varves. A total of 256 laminae couplets were counted, which suggests that the two eruptions were ca. 256 years apart. Below the second ash, the laminations continue (187 couplets) to a depth of $12.68 \mathrm{~m}$. From 12.68-13.25 m are thick layers of inorganic ( $<4 \%$ organics; $<2 \%$ carbonates) clay, silt, and fine sand. Magnetic susceptibility measurements are extremely high in this interval.

The inorganic layers at the base of the core were probably deposited at the end of the last glaciation, when minerogenic material was introduced from glacial meltwater and solifluction. High magnetic susceptibility values suggest considerable input of clastic material in late-glacial time. The laminations between and below the two late-glacial ash layers may represent a time when Trail Lake and Yellowstone Lake were part of a large proglacial lake system and the water depth at the coring site was much deeper than at present. Similar evidence of a proglacial lake has been noted in lakes marginal to Yellowstone Lake (Baker, 1976; Sherrod, 1979). As late-Pleistocene ice receded, water levels dropped and the two basin became isolated. Trail Lake was no longer deep enough to preserve annual laminations, and laminated sediment was replaced by fine detritus gyijta. Based on comparison with other records in the region, the gyttja was deposited during the Holocene when the lake production was high and the slopes were covered by forest. Layers of diatom activity in the lower half of the gyttja unit suggest brief episodes of high algal production, that seem to be associated with the early Holocene warm, dry period.

\section{CHRONOLOGY}

Five charcoal samples have been submitted for accelerator mass spectrometry (AMS) at the University of Arizona in order to establish a chronology for the record. These age determinations are not available at the time of this report, which limits our ability to interpret the records and reconstruct the environmental history. For that reason, the results and discussion should be considered preliminary and somewhat speculative. Using the age of the Glacier Peak ash (11.8 ka at $12.24 \mathrm{~m})$, the lowest depth of gyttja as the beginning of the Holocene (10 ka at $11.15 \mathrm{~m})$, and the mud-water interface $(0 \mathrm{ka}$ at $3.22 \mathrm{~m})$, we can develop crude age-vs-depth relations for the core. The late-glacial period (10-14 ka?) refers to the assemblages before $11.15 \mathrm{~m}$ depth, the early Holocene $(10-5 \mathrm{ka})$ is assigned to a depth of 11.15 $5.90 \mathrm{~m}$, and the late-Holocene (5 ka to present) extends from 5.90-3.22 $\mathrm{m}$ (the mud-water interface).

\section{VEGETATION HISTORY}

The Trail Lake pollen record differs from others in the Absaroka region of southern YNP and GTNP, and without a radiocarbon-age chronology the differences are difficult to evaluate. Prior to the deposition of the Glacier Peak ash (ca. $11.8 \mathrm{ka}$ ), the pollen record is dominated by high percentages of Pinus, including $P$. contorta-type and $P$. albicaulistype. Pollen of Picea (spruce), Abies (fir), Juniperus-type (juniper), Salix (willow), Betula (birch), and $P$. tremuloides (quaking aspen) are also present in significant amounts (Fig. 3). The

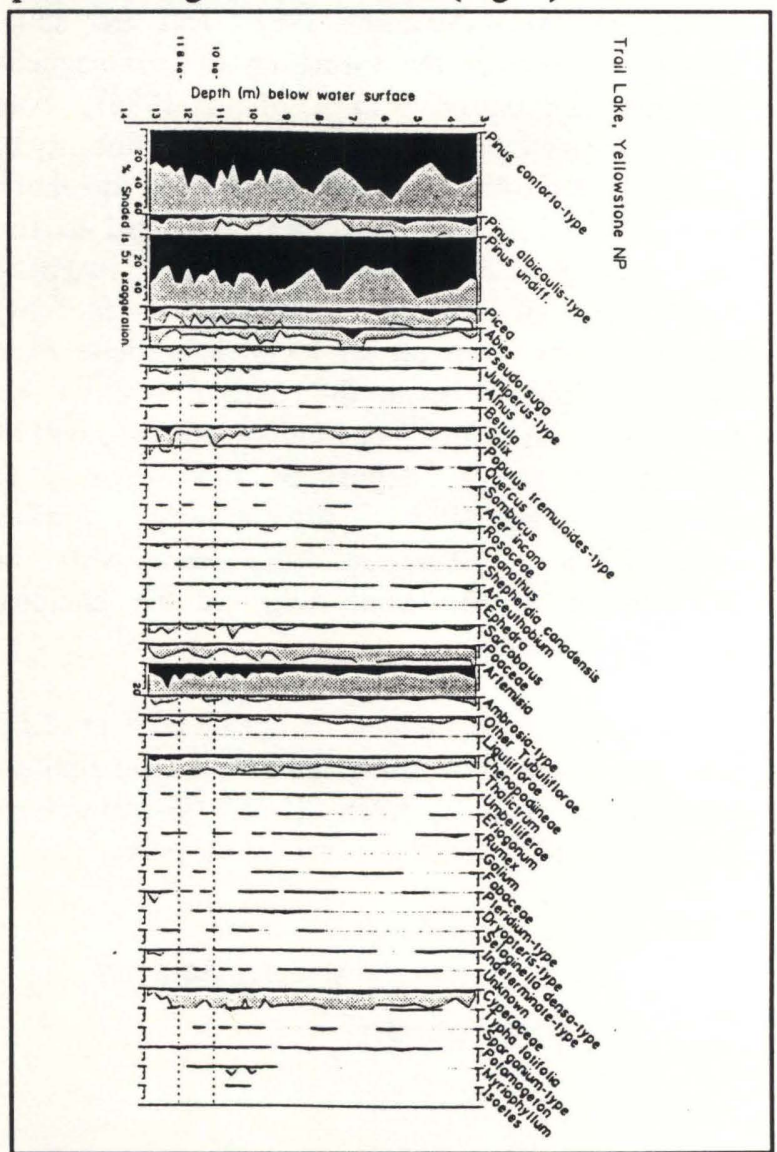

Figure 3. Pollen percentage data for selected taxa. Age estimates are based on the assignment of the ash to the erution of Glacier Peak at $11.8 \mathrm{ka}$ (Whitlock, 1993) and the increase in organic content of the core representing the brginning of the Holocene (10 ka). 
presence of trace amounts of Pseudotsuga (Douglas fir) pollen in the late-glacial period is surprising, but it is noted at Cub Creek Pond (Waddington and Wright, 1974) and Buckbean Fen (Baker, 1976). The Trail Lake record quite likely indicates the local occurrence of Douglas fir in small numbers, because the pollen is not dispersed long distances (Whitlock, 1993). Douglas fir grows today on the Promontory between the Southeast and South arms of Yellowstone Lake, but it is uncommon in southern YNP. The non-arboreal component in the lateglacial period is dominated by Artemisia (sagebrush or wormwood), Gramineae (grass), Asteraceae (composites), and Chenopodiineae (saltbush), although their percentages are low and no taxa indicate alpine conditions.

The vegetation at this time was probably an open pine forest with lodgepole pine, whitebark pine, Engelmann spruce, subalpine fir, common juniper, and some Douglas fir. There is no evidence of tundra during this interval, unlike contemporary assemblages in the region. Birch, willow, and aspen probably grew in mesic and riparian sequences. Overall, the vegetation matches surface sample data from high-elevation forests in the vicinity of Trail Lake (Whitlock, 1993), with spruce, fir, and whitebark pine growing in the coldest most humid areas, and lodgepole pine favoring disturbed sites. Douglas fir may have grown in sunny protected areas.

Between the $11.8 \mathrm{ka}$ and the beginning of the Holocene, the pollen assemblages feature high percentages of Pinus contorta-type and $P$. albicaulis-type. Picea, Abies, Betula, Salix, and Populus are present in lower percentages than before and the non-arboreal components also decreases. Pseudotsuga and Quercus (oak, which was probably blown from distant sources) are present in trace amounts, as is Arceuthobium (mistletoe). The pollen data suggest that the forest was similar to that of the present-day mixed pine, spruce, fir forest around the lake. Pinus contorta was abundant in areas of disturbance. The decrease in wet-ground indicators suggest a less boggy landscape than at the beginning of late-glacial time.

The early Holocene is marked by decreased percentages of Pinus albicaulis-type pollen and a predominance of $\boldsymbol{P}$. contorta-type. Juniperus-type, Alnus (alder), Arceuthobium percentages are slightly higher than before, and Pseudotsuga and Quercus are present consistently. The absence of mesophytic conifers and the abundance of lodgepole pine and juniper (referred to Juniperus communis) suggests that this was the warmest driest period in the record, but the registration of drought is weaker than in other nearby records. In the upper part of the record (above $6 \mathrm{~m}$ depth), slightly increased percentages of Pinus albicaulis-type, Picea, and Abies in the late Holocene suggest a return to cool, humid conditions. Chenopodiineae decreases, while Salix increases, indicating the loss of dry sites and an expansion of wetlands around the lake. The onset of cool humid conditions marks the transition to modern climate and the establishment of the present-day vegetation.

The record is distinctive from others in the Absaroka region (Whitlock, 1993) in several ways. First, it lacks both a period of tundra prior to the deposition of Glacier Peak ash and a period of spruce parkland just after the deposition of the ash. Both of these periods are very striking in most of the pollen records from the southern YNP/GTNP. It is possible that we did not retrieve the complete lateglacial record at Trail Lake, and a tundra pollen assemblage would have been present in deeper sediments. Even so, the lack of evidence of a spruce parkland during or just after deposition of the Glacier Peak cannot be attributed to missing record and raises some intriguing questions: Did spruce parkland develop in the Trail Lake area a few millennial before it appeared at other sites? Or, was this vegetation period missing or expressed differently at Trail Lake?

Second, the steady appearance of Pinus contorta-type and Pseudotsuga pollen in the lateglacial suggests that Trail Lake may have been an early center of colonization for temperate taxa. Perhaps the protected valleys of the upper Yellowstone drainage provided suitable shelter for these taxa early on in the deglacial transition. A third difference between Trail Lake and other records in the Absaroka region is the relatively weak expression of early Holocene warm/dry conditions. At sites in southern YNP/GTNP, increased percentages of Pinus contorta-type, Pseudotsuga, and sometimes Populus pollen imply an expansion of xerophytic species and an increase in disturbance in the early Holocene. This signal is muted at Trail Lake, where the vegetation history has been fairly complacent for the last 11,000 years. 


\section{FIRE HISTORY}

The Trail Lake charcoal record will be analyzed in more detail when charcoal accumulation rate data are available. Charcoal concentration and magnetic susceptibility data, however, show trends that seem to be signficant. Background levels of charcoal are generally low in the late-glacial period, increase abruptly at $11.80 \mathrm{~m}$ depth to a maximum in the early Holocene, and decrease in the late Holocene. Two intervals of low charcoal concentrations are also noted between 11.80-10.70 $\mathrm{m}$ and 8.70-8.00 $\mathrm{m}$ depth. The magnetic susceptibility record shows that values were high in the late-glacial, low in the early Holocene (when charcoal concentration is high), high from 8.00-6.60 $m$ depth (when charcoal concentration is high), and generally low in the late Holocene (when charcoal concentration is low).

The charcoal and magnetic susceptilibity records suggest changes in the amount of burnable biomass and the delivery of charcoal by airborne fall-out, streams, and slopewash processes through time (Fig. 3). The trends generally track the pollen changes, which implies that fire occurrence was strongly controlled by vegetation and climate on millennial time scales. During the late-glacial period of cool humid conditions and open subalpine vegetation, fires were probably infrequent and produced little charcoal. With increased warming, the forest became more closed and fire incidence increased. The expansion of lodgepole pine in the early Holocene marks the time of greatest charcoal concentration, suggesting considerable burning in the watershed. The low background levels of magnetic susceptibility in the early Holocene implies that most of the charcoal was from airborne fall-out as opposed to secondary charcoal introduced from erosion in non-fire years. The decline in background charcoal fits the pollen changes toward more mesophytic taxa. Apparently, the late Holocene featured less burning as a result of cooler more humid conditions.

Charcoal peaks in the concentration data imply fire events throughout the record. The closely spaced peaks in the early Holocene suggest a short fire return interval during the period of greatest summer drought. In the late Holocene, peaks become more widely spaced indicating fewer fires with the establishment of cool conditions. Several of the charcoal peaks correlate with peaks in magnetic susceptibility data. This coincidence suggests that the fire event occurred locally in the watershed and was severe enough to cause masswasting or increase run-off (Meyer et al., 1995). When a chronology is available these data will be used to calculate local fire frequency and identify trends in background charcoal.

\section{$\downarrow \quad$ CONCLUSIONS}

Our understanding of the climate, vegetation, and fire history in Yellowstone National Park and Grand Teton National Park is based on a series of paleoecologic sites located along environmental gradients. Variations in climate and vegetation are inferred from pollen and plantmacrofossil records that span the last $14,000 \mathrm{yr}$ and also from a comparison of the paleoecologic record with independent estimates of past climate change. Information on fire frequency in YNP/GTNP comes from historical and dendrochronologic records (e.g., Romme, 1982; Barrett, 1994) and the analysis of charcoal deposited in the sediments of lakes (e.g., Millspaugh and Whitlock, 1995). These data allow us to identify the sequence of climatic changes that has shaped fire regimes since the last ice age; they also disclose the response of forest communities to variations in disturbance regime. Comparison of YNP/GTNP records with other areas of the West suggests that regional variations in vegetation and climate are a consequence of large-scale changes in the climate system that affected all of North America (Barnosky et al., 1987; Thompson et al., 1993). In YNP/GTNP as elsewhere, the present forest associations have developed only in the last few millennia with the establishment of cool humid conditions (Baker 1983; Beiswenger, 1991; Whitlock, 1993). The pollen data from Trail Lake do not reflect the variations in vegetation and climate as well as other records from the Absaroka region, and the explanation for this is not yet clear. The location of the site may have protected it from climatic extremes and thus allowed early colonization of conifers after deglaciation as well as mitigated the effects of early Holocene drought.

Although the interpretation of the Trail Lake fire history is preliminary, the abundance of charcoal in the record of the last ca. $12 \mathrm{kyr}$ indicates that fire has been an important disturbance mechanism in this region for millennia. The variable nature of the charcoal record argues against a long-term fire cycle. On the contrary, charcoal records from Trail and other lakes suggest that the 
fire frequency has been nonstationary and changed continuously in response to varying climate conditions.

Examination of fire on multiple time scales through the comparison of dendrochronologic and lake-sediment records will improve our ability to study the response of subalpine forests to climate changes in the next century. In addition to changes in species ranges and extirpations, a probable effect of global warming will be an increase in the incidence of large fires (Sandenburgh et al., 1987; Price and Rind, 1994; Balling et al., 1992). Fire frequency, size, and severity, more than other ecological processes, will be directly and

immediately affected by changes in temperature and effective moisture (Overpeck et al., 1990). Subalpine forests have been targeted as especially vulnerable to future climate changes (Bartlein et al., 1997; Romme and Turner, 1991), but the mechanisms causing their decline bear further investigation.

\section{ACKNOWLEDGMENTS}

We thank John Varley (NPS) and Hank Harlow (University of Wyoming) for their support of this project. We also appreciate the great logical support provided by John Lounsbury, Alice Siebecker, and Frank and Beverly Ford of Lake Ranger District. Bob Gresswell, Susan Gutenberger, Steve Klein, and Pat Connolly were able and invaluable field assistants. Sarah Millspaugh helped with the charcoal analysis.

\section{$\downarrow \quad$ Literature Cited}

Baker, R. G. 1976. Late Quaternary vegetation history of the Yellowstone Lake basin, Wyoming. U.S. Geological Survey Professional Paper 729-E: E1-E48.

---. 1983. Holocene vegetational history of the western United States. Pages 109-127 in H. E. Wright Jr., editor. Late-Quaternary environments of the United States. University of Minnesota Press, Minneapolis.
Balling, R.C. Jr., Meyer, G.A., and Wells, S. G. 1992. Climate change in Yellowstone National Park: is the drought related risk of wildfires increasing? Climatic Change 22: 34-35.

Barnosky, C. W., Anderson, P. M., and Bartlein, P. J. 1987. The northwestern U.S. during deglaciation; vegetational history and paleoclimatic implications. Pages 289-321 in W. F. Ruddiman and H E. Wright, Jr., editors. North America and adjacent oceans during the last deglaciation. Vol. K-3. Geological Society of America, Boulder, Colorado.

Barrett, S. W. 1994. Fire regimes on andesitic mountain terrain in northeastern Yellowstone National Park, Wyoming. International Journal of Wildland Fire 4: 65-76.

Bartlein, P. J., Whitlock, C., and Shafer, S. 1997. Future climate in the Yellowstone National Park region and its potential impact on vegetation. Conservation Biology 11: 782792.

Beiswenger, J.M. 1991. Late Quaternary vegetational history of Grays Lake, Idaho. Ecological Monographs 61: 165-182.

Clark, J. S. 1990. Fire and climate change during the last 750 years in northwestern Minnesota. Ecological Monographs 60: 135-159.

Dean, W.E. 1974. Determination of carbonate and organic matter in calcareous sediments and sedimentary rocks by loss on ignition: comparison with other methods. Journal of Sedimentary Petrology 44: 242-248.

Despain, D. G. 1987. The two climates of Yellowstone National Park. Proceedings of the Montana Academy of Sciences 47: 1120.

---. 1990. Yellowstone Vegetation; Consequences of Environment and History in a Natural Setting. Boulder: Roberts Rinehart Publishers. 
Faegri, K., Kaland, P.E., and Krzywinski, K. 1989. Textbook of pollen analysis (fourth edition). New York: John Wiley and Sons, $328 \mathrm{p}$.

Long, C.J., Whitlock, C., Bartlein, P.J., Millspaugh, S.H. (in review). A 9000-year fire history from the Oregon Coast Range, based on a high-resolution charcoal study. submitted to Canadian Journal of Forest Research.

McAndrews, J.H., Berti, A.H., and Norris, G. 1973. Key to the Quaternary pollen and spores of the Great Lakes region. Life Sciences Miscellaneous Publications, Royal Ontario Museum, Toronto.

Meyer, G.A., Wells, S.G., Jull, A.J.T. 1995. Fire and alluvial chronology in Yellowstone National Park: Climatic and intrinsic controls on Holocene geomorphic processes. Geological Society of America Bulletin 107: 1211-1230.

Millspaugh, S.H. and Whitlock, C. 1995. A 750year fire history based on lake sediment records in central Yellowstone National Park, USA. The Holocene 5: 283-292.

Moore, P.D. and Webb, J.A. 1978. An illustrated guide to pollen analysis. John Wiley \& Sons, New York.

Overpeck, J.T., Rind, D. and Goldberg, R. 1990. Climate-induced changes in forest disturbance and vegetation. Nature 343: 51-53.

Patterson, W. A., Edwards, K. J., and Maguire, D. J. 1987. Microscopic charcoal as a fossil indicator of fire. Quaternary Science Reviews 6: 3-23.

Price, C. and Rind, D. 1994. The impact of a $2 \mathrm{XCO}_{2}$ climate on lightning-caused fires. Journal of Climate 7: 1484-94.

Romme, W. H. 1982. Fire and landscape diversity in subalpine forests of Yellowstone National Park. Ecological Monographs 52: 199-221.
Romme, W.H. and Turner, M.G. 1991. Implications of global climate change for biogeographic patterns in the Greater Yellowstone Ecosystem. Conservation Biology 5: 373-86.

Rummery, T.A., Bloemendal, J., Dearing, J., Oldfield, F. and Thompson, R. 1979. The persistence of fire-induced magnetic oxides in soils and lake sediments. Annales de Geophysiqua 35: 103-107.

Sandenburgh, R., Taylor, C. and Hoffman, J.S. 1987. Rising carbon dioxide, climate change, and forest management: an overview. In The Greenhouse Effect, Climate Change and U.S. Forests. pp. 113121. Edited by W.E. Shands and J.S. Hoffman. The Conservation Foundation, Washington, DC.

Sherrod, B.S. 1979. Paleolimnology of Alder Lake and its implications for Holocen tectonics in Yellowstone National Park. M.S. thesis, University of Pittsburgh.

Swanson, F. J. 1981. Fire and geomorphic processes. In Proceedings Fire Regimes and Ecosystem Properties. Edited by $\mathrm{H}$. A. Mooney, T. M. Bonnicksen, N. L. Christensen, J. E. Lotan, and W. A. Reiners. USDA For. Serv. Gen. Tech. Rep. WO-28. pp. 401-420.

Thompson, R., and Oldfield, F. 1986. Environmental Magnetism. Allen and Unwin, London.

Thompson, R.S., Whitlock. C., Harrison, S.P., Spaulding, W.G., and Bartlein, P.J.. 1993. Climatic changes in the western United States since $18,000{ }^{14} \mathrm{C}$ yr B.P. Pages 468 513 in H.E. Wright Jr., J.E. Kutzbach, T. Webb III, W.F. Ruddiman, F.A. StreetPerrott, and P.J. Bartlein, editors. Global climates since the Last Glacial Maximum. University of Minnesota Press, Minneapolis, MN. 
Waddington, J.C.B., and Wright, H.E., Jr. 1974. Late Quaternary vegetational changes on the east side of Yellowstone National Park, Wyoming. Quaternary Research 4: 175184.

Whitlock, C. 1993. Postglacial vegetation and climate of Grand Teton and southern Yellowstone National Parks. Ecological Monographs 63: 173-98.

Whitlock, C., and Bartlein, P.J. 1993. Spatial variations of Holocene climatic change in the Yellowstone region. Quaternary Research 39: 231-238.

Whitlock, C., Bartlein, P.J., and Van Norman, K.J. 1995. Stability of Holocene climate regimes in a mountainous region. Quaternary Research 43: 433-436.

Whitlock, C. and Millspaugh, S. 1996. Testing assumptions of fire history studies: An examination of modern charcoal accumulation in Yellowstone National Park. The Holocene 6: 7-15.
---. in press. Holocene vegetation and fire history of the Greater Yellowstone Ecosystem; with emphasis on the Yellowstone Lake region. submitted to "Human Settlement of the Foothill-Mountain Environments" Proceedings of the Rocky Mountain Anthropology Conference in Jackson WY, Sept. 30-Oct. 2, 1993.

Whitlock, C., Millspaugh, S., Bartlein, P.J., and Shafer, S.H. 1994. Postglacial fire frequency and its relation to long-term vegetational and climatic changes in Yellowstone National Park. Final Report to the University of Wyoming-National Park Service Research Center.

Whitlock, C., Bradbury, J.P., and Millspaugh, S.H. 1997. Controls on charcoal distribution in lake sediments: case studies from Yellowstone National Park and Northwestern Minnesota. In Sediment Records of Biomass Burning and Global Change (J.S. Clark, H. Cachier, J.G. Goldhammer, and B.J. Stocks, eds). Springer Verlag. 